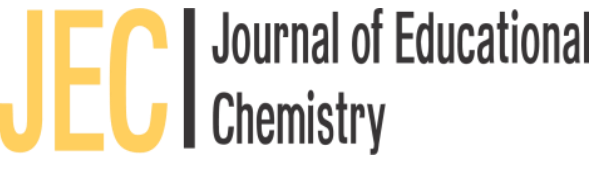

\section{Peningkatan Hasil Belajar dan Keaktifan Belajar Kimia Melalui Model Pembelajaran Disco Winshop}

\author{
Sri Lestari \\ Sekolah Menengah Atas Negeri 1 Pamotan Rembang \\ 1E-mail: srilestarikimia@gmail.com
}

\begin{abstract}
This Classroom Action Research (CAR) aims to determine the effect of the implementation of Disco Winshop models towards learning outcome and activity of X MIPA2 students, on the chemistry bonding subject matter at SMA Negeri 1 Pamotan. This study was conducted in two cycles, each cycle consist of four phases: planning, action, observation and reflection. The subjects were X MIPA 2 students at SMA Negeri 1 Pamotan, which is amounted to 35 people, consisting of 12 male students and 23 female students. Data analysis was performed with a descriptive quantitative technique. The results showed an increase in student learning outcomes and activities in the chemistry bonding materials. In the first cycle was the student's learning outcome was 64 , classical learning completeness was $57 \%$ and the student's activities was 81.71. In the second cycle was the student's learning outcome was 85, classical learning completeness was 74\% and the student's activities was 91.33 .
\end{abstract}

Keywords: disco wishop learning model, learning outcome, student's activites, chemistry bonding

118

Copyright (C) 2019 JEC | ISSN 2715-3029 (p) 2685-4880 (e)

Volume 1, Nomor 2, 2019 


\begin{abstract}
Abstrak
Penelitian Tindakan Kelas (PTK) ini bertujuan untuk mengetahui pengaruh penerapan model pembelajaran Disco Winshop terhadap peningkatan hasil belajar dan keaktifan peserta didik kelas X MIPA 2 pada materi Ikatan Kimia di SMA Negeri 1 Pamotan. Penelitian ini dilakukan pada 2 siklus, tiap siklus terdiri atas empat tahapan, yaitu perencanaan, tindakan, observasi dan refleksi. Subjek Penelitian adalah peserta didik kelas X MIPA 2 SMA Negeri 1 Pamotan yang berjumlah 35 orang yang terdiri dari 12 peserta didik laki-laki dan 23 peserta didik perempuan. Analisis data menggunakan Teknik deskriptif kuantitatif. Hasil penelitian menunjukkan adanya peningkatan hasil belajar dan keaktifan peserta didik pada materi ikatan kimia. Pada siklus I diperoleh skor rata-rata hasil belajar 64, ketuntasan klasikal 57\%, dan aktivitas peserta didik 81,71\%. Pada siklus II diperoleh skor rata-rata hasil belajar 85, ketuntasan klasikal 74\%, dan aktivitas peserta didik 91,33\%.
\end{abstract}

Kata Kunci: model pembelajaran disco winshop, hasil belajar, keaktifan, ikatan kimia

\title{
Pendahuluan
}

Undang-undang Nomor 20 Tahun 2003 menjelaskan bahwa tujuan Pendidikan nasional di Indonesia adalah mencerdasakan kehidupan bangsa. Untuk itu pelrunya kurikulum Pendidikan nasional sebagai wadah untuk menentukan arah Pendidikan nasional (Clorawati, Salatri dan Hermansyah, 2017). Seiring dengan berkembangnya zaman, kurikulum seharusnya juga mengikuti perkembangan tersebut sebagai langkah untuk mengikuti perkembangan zaman (Winda, 2016). Kurikulum 2013 yang berlaku saat ini merupakan rangkaian penyempurnaan terhadap kurikulum sebelumnya, yang lebih menekankan pada kompetensi berbasis afektif, kognitif dan psikomotor (Nurmadiah, 2014). Pada kurikulum 2013 menuntut pembelajaran menggunakan pendekatan scientifik dan tematik integratif, serta memadukan antara kemampuan afektif, kognitif dan psikomotor (Lestari, 2015). Harapannya proses pembelajaran di kelas hasil belajar peserta didik haruslah juga mencakup ketiga kemampuan tersebut (Lestari, Hermansyah dan Salatri, 2017). Pelajaran kimia di SMA pada kurikulum 2013 merupakan materi yang diperoleh dan dikembangkan berdasarkan eksperimen untuk mencari penyelesaian yang berhubungan dengan gejala alam (Waluyo dan Parmin, 2014) Untuk itu ilmu kimia perlu mengkolaborasikan antara keterampilan dan penalaran (Simanjuntak, Salastri dan Ekvinawati, 2017).

Fenomena yang dialami oleh peserta SMA Negeri 1 Pamotan mempunyai hasil belajar kimia peserta didik kelas $\mathrm{X}$ MIPA pada Kompetensi Ikatan Kimia kurang baik, yaitu dari 35 peserta hanya 13 peserta didik yang tuntas. Selain kompetensi pengetahuannya yang tidak baik keaktifan peserta didik juga kurang ini dapat dilihat dari proses pembelajaran peserta didik yang hanya menerima apa yang diberikan guru. Mereka tidak berusaha untuk mendapatkan yang lebih. Berdasarkan observasi diperoleh data bahwa faktor yang mempengaruhi kurangnya kompetensi peserta didik dalam pembelajaran kimia adalah penggunaan metode pembelajaran yang dilaksanakan masih berpusat pada guru, peserta 
tidak diarahkan untuk kemampuan berpikir kreatif dan menguasai konsep berdasarkan hasil riset di lapangan.

Salah satu model pembelajaran kimia yang mampu untuk meningkatkan kompetensi peserta didik adalah model pembelajaran yang penulis namakan model Disco Winshop. Model pembelajaran ini merupakan model pembelajaran Discovery dimana pada tahap verifikasi dilakukan window shopping yaitu dengan data dipajang dan ada salah satu anggota kelompok yang bertindak sebagai sales promotion dan anggota yang lain menjadi pengunjung di kelompok lain. Model ini akan membuat pembelajaran lebih bermakna karena akan mengubah kondisi belajar yang pasif menjadi aktif dan kreatif serta mengubah pembelajaran yang semula teacher oriented ke student oriented (Dina, Mawarsari , \& Suprapto, .

\section{Metode Penelitian}

Penelitian yang digunakan pada penelitian ini adalah penelitian tindakan kelas (PTK), dimana melakukan penelitian terhadap kegiatan belajar berupa tindakan yang sengaja dimunculkan dan terjadi dalam sebuah kelas secara bersama (Uno, 2014). Subyek penelitian adalah peserta didik kelas X IPA 2 SMA Negeri 1 Pamotan tahun ajaran 2017/2018. PTK akan dilaksanakan menggunakan model Disco Winshop dalam 2 siklus, pada pokok bahasan ikatan kimia. PTK dilaksanakan dengan empat tahap untuk setiap siklusnya, yaitu tahap perencanaan tindakan (planning), tahap pelaksanaan tindakan (action), tahap pengamatan atau observasi (observation) dan tahap refleksi (reflection) (Purnomo, 2015).

Pada penelitian ini instrumen penelitian yang digunakan adalah berupa tes hasil belajar pada akhir siklus, lembar observasi aktivitas guru dan peserta didik. Tes pada akhir siklus bertujuan untuk mengetahui penguasaan materi ikatan kimia oleh peserta. Sedangkan observasi 120

Copyright (C) 2019 JEC | ISSN 2715-3029 (p) 2685-4880 (e) Volume 1, Nomor 2, 2019 dilakukan menggunakan instrumen observasi untuk mengamati aktivitas guru dan peserta didik sebagai pedoman keberhasilan proses pembelajaran dalam satu siklus untuk dijadikan bahan refleksi untuk siklus selanjutnya. Instrumen observasi adalah suatu proses pengamatan dan pencatatan secara sistematis, logis, objektif, dan rasional mengenai berbagai fenomena, baik dalam situasi yang sebenarnya maupun dalam situasi buatan untuk mencapai tujuan tertentu (Hardiani dan Wardani, 2017). Lembar observasi aktivitas peserta didik, digunakan untuk mengetahui sejauh mana keaktifan dan keikutsertaan peserta didik dalam mengikuti proses belajar dengan menggunakan model Disco Winshop (Winarni, Santosa dan Ramli, 2016).

Analisis data penelitian ini menggunakan analisis deskriptif kualitatif, dengan data yang dianalisis ini adalah nilai tes prestasi belajar kimia pada kompetensi dasar ikatan kimia, data pengamatan aktivitas guru dan peserta didik dalam kegiatan belajar mengajar. Analisis data yang digunakan adalah nilai rata-rata hasil belajar, daya serap klasikal, dan ketuntasan belajar/ketuntasan klasikal. Untuk data hasil observasi akan digunakan untuk merefleksikan siklus yang telah dilakukan dan dianalisis secara deskriptif. Analisis data observasi aktivitas guru dan peserta didik menggunakan penilaian. Semakin tinggi nilai yang dihasilkan maka akan semakin baik pembelajaran atau sebaliknya. Sebagai indikator keberhasilan pembelajaran adalah berupa hasil belajar dan aktivitas peserta didik. Kriteria keberhasilan tindakan diterapkan berdasarkan nilai ketuntasan hasil belajar dari sekolah dan pertimbangan penelitian. Kriteria keberhasilan dari tindakan pada penelitian ini adalah daya serap meningkat untuk setiap silkusnya, hasil belajar dari siklus adalah tuntas bila setiap peserta didiknya mendapatkan nilai $=75$ dan tuntas secara klasikal dimana $70 \%$ serta aktivitas guru dan peserta didik yang diamati 
mengunakan lembar observasi mencapai kategori baik.

\section{Hasil Penelitian dan Pembahasan}

Penelitian dilaksanakan pada kelas $\mathrm{X}$ IPA 2 SMA Negeri 1 Kota Pamotan, dengan jumlah peserta didik 35 orang. Hasil observasi awal, diperoleh data ketuntasan klasikal mata pelajaran kimia pada pokok ikatan kimia adalah $37,14 \%$, yang berarti belum mencapai standar ketuntasan yaitu $70 \%$.

\section{Siklus I}

Pada siklus I ini guru memulai dengan memberikan stimulus dengan memperlihatkan salah satu contoh senyawa ion yaitu garam dapur dan menayakan pada anak rumus senyawa garam dapur. Kemudian menampilkan video reaksi logam $\mathrm{Na}$ dengan air yang sangat eksplosif dan gas klor yang beracun. Guru juga menayangkan video orang yang bersedakah untuk menggambarkan prinsip pada ikatan ion. Melalui tayangan video tersebut timbul pertanyaan pada peserta didik. Mengapa logam Na yang sifatnya eksplosif dan gas klor yang beracun jika sudah bergabung membentuk $\mathrm{NaCl}$ (garam dapur) tidak berbahaya lagi? Bagaimanakah proses pembentukan ikatan ion pada garam dapur?. Kemudian peserta mencari data tentang ikatan ion dengan cara studi literatur baik buku maupun internet. Untuk pertemuan pertama siklus 1 hanya sampai pada tahap data collecting. Pada pertemuan selanjutnya guru mengingatkan kembali pada peserta didik tentang tujuan pembelajaran dan diakhir pembelajaran akan dilakukan evaluasi. Peserta didik berkelompok sesuai dengan kelompoknya dan melanjutkan pada tahap berikutnya. Peserta didik berdiskusi dengan kelompoknya mengerjakan lembar kerja yang diberikan guru. Melalui pembelajaran ini peserta didik mampu menjelaskan proses terbentuknya ikatan ion dengan menggunakan kartu cocok sesuai dengan lembar kerja. Hasil diskusi dituliskan pada kertas manila. Hasil diskusi masing-masing kelompok yang ditulis pada kertas manila kemudian dipajang didinding kelas. Salah satu anggota kelompok bertindak sebagai sales promotion yang tugasnya mempromosikan dan menjawab pertanyaan yang diajukan anggota kelompok lain yang berkunjung. Sedangkan anggota yang lain dapat berkunjung ke kelompok lain untuk bertanya sambil membandingkan hasil kelompoknya dengan kelompok yang dikunjungi. Setiap pengunjung wajib memberikan komentar tentang hasil dari kelompok yang dikunjungi. Inilah yang dimaksud dengan penyajian model Window shoping. Pada tahap terakhir guru bersama peserta didik menyimpulkan pembelajaran. Pada kegiatan penutup guru memberikan penguatan, merefleksi kegiatan pembelajaran dan memberikan tes sebagai hasil tes pada siklus I.

Berdasarkan hasil tes evaluasi pada siklus I diperoleh rata-rata hasil belajar pada siklus I ini mencapai 64 dengan ketuntasan klasikal 57\%. Hasil belajar ini secara kuantitatif masih di bawah dari kriteria ketuntasan minimal yaitu 75 dan ketuntasan klasikal $<70 \%$. Berdasarkan data ini menunjukan bahwa masih banyak peserta didik yang belum sepenuhnya mampu menjelaskan proses terbentuknya ikatan ion. Kesalahan yang umum dilakukan peserta didik adalah dalam menuliskan ion yang terjadi setelah melepaskan atau menerima elektron. Selain itu masih banyak peserta didik yang belum sepenuhnya mampu menuliskan rumus senyawan ion jika diberikan ion-ion pembentuknya. Kesalahan yang umum dilakukan peserta didik adalah tidak menuliskan jumlah atom atau angka indeks. Kemudian keaktifan peserta didik dalam mengikuti kegiatan pembelajaran pada siklus I sudah tergolong tinggi terbukti dari rata-rata skor 81,71 dan hasil observasi tentang kinerja guru menunjukan bahwa rata-rata skor kinerjanya mencapai $92 \%$.

Berdasarkan hasil tes dan hasil observasi pada siklus I dijadikan refleksi untuk pertemuan atau siklus selanjutnya. Karena ini merupakan model pembelajaran yang baru mereka belum terbiasa dengan model 
pembelajaran discovery yang dilanjutkan dengan window shopping. Hasil diskusi penulis dan observer ada beberapa hal yang perlu diperbaiki. Salah satunya adalah jumlah anggota tiap kelompok dikurangi karena dengan berjumlah 6 kurang efektif. Penataan ruang kurang menguntungkan karena terlalu sempit untuk memajang hasil diskusi dan tidak efektif karena untuk berkunjung terlalu jauh di depan kelas dan dibelakang kelas. Untuk peserta didik yang berkunjung juga jarang yang memberikan komentar . Selain itu untuk pelaksanaan pembelajaran yang dilakukan dua pertemuan yaitu 1 jam pertemuan (jp) dan 2 jp juga kurang efektif sehingga untuk siklus dua dilakukan satu kali pertemuan. Sehingga untuk siklus II dilakukan dengan perbaikan tiap kelompok beranggotakan 4 orang dan ruang pindah di laboratorium kimia yang tempatnya lebih luas. Untuk komentar ditulis di kertas warna dengan tiap kelompok warnanya sama sehingga dapat diketahui kelompok mana yang anggotanya tidak berkunjung dan tidak komentar. Selain itu pada siklus ke dua dilakukan hanya satu pertemuan dengan tiga jam pelajaran sehingga lebih efektif waktu.

\section{Siklus II}

Pada siklus II ini guru memulai memberikan stimulus dengan memperlihatkan salah satu contoh senyawa kovalen yaitu air dan menanyakan pada anak rumus molekul air. Pada proses pernafasan dibutuhkan gas oksigen dan mengeluarkan gas karbondioksida, yang juga merupakan contoh senyawa kovalen. Kemudian menampilkan video pemanfaatan gas nitrogen pada makanan. Melalui tayangan video tersebut timbul pertanyaan pada peserta didik. Bagaimanakah proses terbentuknya ikatan kovalen pada molekul air, gas oksigen, gas karbondioksida dan nitrogen?. Kemudian peserta didik mencari data tentang ikatan kovalen dengan cara studi literatur baik buku maupun internet. Peserta didik berdiskusi dengan kelompoknya mengerjakan lembar kerja yang diberikan guru. Dapat menjelaskan proses terbentuknya ikatan ion dengan menggunakan kartu cocok sesuai dengan lembar kerja. Hasil diskusi dituliskan pada kertas manila. Hasil diskusi masing-masing kelompok yang ditulis pada kertas manila kemudian dipajang di dinding kelas. Salah satu anggota kelompok bertindak sebagai sales promotion yang tugasnya mempromosikan dan menjawab pertanyaan yang diajukan anggota kelompok lain yang berkunjung. Sedangkan anggota yang lain dapat berkunjung ke kelompok lain untuk bertanya sambil membandingkan hasil kelompoknya dengan kelompok yang dikunjungi. Setiap pengunjung wajib memberikan komentar tentang hasil dari kelompok yang dikunjungi. Inilah yang dimaksud dengan penyajian model Window shopping. Pada tahap selanjutnya guru bersama peserta didik menyimpulkan pembelajaran. Pada kegiatan penutup guru memberikan penguatan, merefleksi kegiatan pembelajaran dan memberikan tes sebagai hasil tes pada siklus II.

Berdasarkan hasil tes evaluasi pada siklus II diperoleh rata-rata hasil belajar mencapai 85 dengan ketuntasan klasikal 74\%. Hasil belajar ini secara kuantitatif sudah di atas dari kriteria ketuntasan minimal yaitu 75 . Ada 26 peserta didik (74\%) yang sudah mencapai ketuntasan belajar dengan nilai $\geq 75$. Sedangkan keaktifan peserta didik dalam mengikuti kegiatan pembelajaran pada siklus II sudah tergolong sangat tinggi terbukti dengan rata-rata skor 91,33 dan hasil observasi tentang kinerja guru menunjukan bahwa rata-rata skor kinerjanya mencapai $95 \%$.

Hasil belajar peserta didik jika dibandingkan antara siklus I dengan siklus II, maka pada siklus II ini rata-rata hasil belajar peserta didik mengalami peningkatan. Sedangkan peserta didik yang mencapai ketuntasn belajar meningkat sebesar $17 \%$ dari siklus I. Proporsi peserta didik yang belum 
tuntas pun mengalami penurunan yaitu dari 15 peserta didik menjadi 9 peserta didik. Walaupum sebenarnya jika dilihat dari materinya ikatan kovalen lebih kompleks dibandingkan ikatan ion, karena macam dari iaktan kovalen lebih banyak. Keaktifan peserta didik dalam mengikuti kegiatan pembelajaran pada siklus I sudah tergolong tinggi terbukti dari rata-rata skor 81,71. Sedangkan untuk keaktifan peserta didik dalam mengikuti kegiatan pembelajaran pada siklus II sudah tergolong sangat tinggi terbukti dari rata-rata skor 91,33. Jika dibandingkan keaktifan peserta didik pada siklus I dan siklu II maka keaktifan peserta didik pada siklus II mengalami peningkatan 9,62 \%. Indikator pada penelitian tindakan kelas ini untuk hasil belajar adalah $70 \%$ peserta didik telah mencapai ketuntasan belajar dan untuk meningkatnya keaktifan peserta didik dalam proses pembelajaran.

Pada penelitian ini menunjukkan bahwa model pembelajaran disco winshop sangat berpengaruh terhadap peningkatan keaktifan belajar peserta didik dalam proses pembelajaran ikatan kimia. Hal ini ditandai dengan berjalannya proses pembelajaran lebih baik dengan meningkatnya hasil belajar yang dilakukan maupun keaktifan peserta didik yang mendukung proses pembelajaran (Setiawan dan Suparmin, 2016). Berdasarkan uraian penelitian ini, maka keaktifan belajar peserta didik pada ikatan kimia dengan diterapkannya model pembelajaran disco winshop menunjukkan adanya peningkatan dari siklus I dan siklus II. Adanya peningkatkan keaktifan belajar peserta didik pada tiap siklus yang dilakukan, merupakan indikasi keberhasilan tindakan yaitu dapat penerapan model pembelajaran disco winshop pada materi ikatan kimia sebagai upaya untuk meningkatkan hasil belajar dan keaktifan peserta didik dalam proses pembelajaran. Keaktifan peserta didik di kelas dipengaruhi oleh adanya faktor yang mendukung yaitu penggunaan model pembelajaran Penggunaan model pembelajaran disco winshop pada prinsipnya berpusat pada peserta didik (student center), sehingga peserta didik yang lebih banyak berperan dan lebih aktif dalam proses pembelajaran (Sanjaya, 2015). Hal ini sejalan dengan penelitian Prayitno dan Dian (2017) mengatakan peningkatan keaktifan peserta didik terjadi karena pembelajaran yang menggunakan model pembelajaran disco winshop memberi kesempatan kepada peserta didik untuk terlibat aktif menemukan jawaban atas konsep-konsep yang mereka pelajari. Meningkatnya keaktifan selama proses pembelajaran dipengaruhi oleh adanya stimulasi belajar yang semakin meningkat dan peserta didik semakin bersemangat dalam belajar karena peserta didik diberi kesempatan untuk menemukan sendiri dengan cara melakukan praktik langsung dan menggali informasi dari pengalaman nyata serta membandingkan data dengan bahan-bahan materi (Putri, Juliani dan Lestari, 2017).

\section{Simpulan dan Saran}

Simpulan

Berdasarkan hasil penelitian menunjukkan bahwa model pembelajaran window shopping memberikan pengaruh dalam proses pembelajaran. Hal ini ditunjukkan dengan adanya peningkatan hasil belajar dan keaktifan peserta didik pada materi ikatan kimia kelas X MIPA 2 SMA Negeri 1 Pamotan melalui penerapan model pembelajaran Disco Winshop. Peningkatan hasil belajar peserta dari siklus 1 ke siklus II mengalami perubahan. Pada siklus I rata-rata kognitif 64 dengan ketuntasan klasikal sebesar $57 \%$ meningkat menjadi rata-rata kognitif 85 dengan ketuntasan klasikal 74\% pada siklus II. Aktivitas peserta didik meningkat dari $81,71 \%$ pada siklus I menjadi $91,33 \%$ pada siklus II, dan aktivitas guru sebesar 92\% pada siklus I meningkat menjadi 95\% pada siklus II.

\section{Saran}

Berdasarkan penelitian yang sudah dilaksanakan, terdapat beberapa hal yang masih kurang terindentifikasi dengan baik. Oleh 
karena itu disampaikan beberapa saran yang didasarkan hasil penelitian ini adalah: (1) Perlu adanya penelitian lain yang memfokuskan pada aspek afektif, karena dalam penelitian ini kurang membahas mengenai aspek tersebut, dan (2) Perlu adanya penelitian lebih lanjut mengenai model pembelajaran lain yang dapat meningkatkan hasil belajar peserta didik, karena proses hasil belajar pada penelitian ini belum rinci.

\section{Daftar Pustaka}

Clorawati, A.R., Salastri, R. \& Hermansyah, A.. 2017. Implementasi Kurikulum 2013 Bagi Guru Kimia di SMA Negeri Sekota Bengkulu. Alotrop, 1 (2): 132-135.

Dina, A., Mawarsari, V. D. \& Suprapto, R.. 2015. Implementasi Kurikulum 2013 Pada Perangkat Pembelajaran Model Discovery Learning Pendekatan Scientific Terhadap Kemampuan Komunikasi Matematis Materi Geometri SMK. JKPM, 2 (1) :22-31.

Hardiani, I.N. \& Wardani, N. S.. 2017. Pengembangan Instrumen Penilaian Sikap Sosial Pembelajaran IPS Kelas IV SD. e-jurnal Mitra Pendidikan, 1 (6):615628.

Lestari, D.A.. 2015. Pendekatan Saintifik dalam Pembelajaran Tematik Untuk Meningkatkan Ketrampilan Bertanya Siswa. Widyagogik. 3 (1):66-79.

Lestari, I. A, Hermansyah, A. \& Salastri, R.. 2017. Hubungan Persepsi Siswa Kelas X MIPA di SMA Negeri Sekota Bengkulu TahunAjaran 2016/2017 Tentang Variasi Gaya Mengajar Guru Dengan Hasil Belajar Kimia. Alotrop, 1 (2):113116.

Nurmadiah. 2014. Kurikulum Pendidikan Islam. Jurnal Al-Afkar, 3 (2):41-54.

124

Copyright (C) 2019 JEC | ISSN 2715-3029 (p) 2685-4880 (e)

Volume 1, Nomor 2, 2019
Prayitno, B.W. \& Dian R. N.. 2017. Meningkatkan Keaktifan Siswa Dengan Model Discovery Learning Pada Konsep Klasifikasi Makluk Hidup. Jurnal Pendidikan Hayati, 3 (4): 136-143.

Purnomo, B.H.. 2015. Metode dan Teknik Pengumpulan Data Dalam Penelitian Tindakan Kelas (Classroom Action Research). Pengembangan Pendidikan, 8 (1): 251-256.

Putri. I. S., Juliani, R. \& Lestari, N.. 2017. Pengaruh Model Pembelajaran Discovery Learning Terhadap Hasil Belajar Siswa dan Aktivitas Siswa. Jurnal Pendidikan Fisika, 6 (2): 91-94.

Sanjaya, W.. 2015. Strategi Pembelajaran Berorientasi Standar Proses Pendidikan. Jakarta: Kencana.

Setiawan, D. \& Suparmin. 2016. Meningkatkan Keaktifan Dan Hasil Belajar Materi Sistem Stater Pada Mata Pelajaran Pemeliharaan Kelistrikan Kendaraan Ringan Dengan Metode Penemuan Terbimbing Pada Siswa Kelas XI TKR SMK Tamansiswa Jetis Tahun Pelajaran 2015/2016. Jurnal Taman Vokasi, 4 (2): 271-277.

Simanjuntak, N. D. P., Salastri, R., \& Elvinawati. 2017. Hubungan Antara Sarana LaboratoriumTerhadap Ketrampilan Proses Sains Siswa Kelas XI MIPA 5 di SMA Negeri 3 Kota Bengkulu. Alotrop, 1 (2): 102-105.

Uno, H. B. 2014. Menjadi Peneliti PTK yang Profesional. Jakarta :Bumi Aksara.

Waluyo, M.E. \& Parmin. 2014. Pengembangan Panduan Praktikum IPA Terpadu Berbasis Inkuiri Terbimbing Tema Fotosintesis Untuk Menumbuhkan Ketrampilan Kerja Ilmiah Siswa SMP. 
Unnes Science Education Journal, 3 (3): 677-684.

Winarni, Santosa, S. \& Ramli, M.. 2016. Penerapan Model Discovery Learning untuk Meningkatkan Oral Activities Siswa SMA. Bioedukasi, 9 (2): 55-61.

Winda , N.. 2016. Implementasi Kurikulum 2013 dalam Pembelajaran Bahasa Indonesia Berbasis Teknologi Informasi dan Komunikasi. Stilistika: Jurnal Bahasa, Sastra, dan Pengajarannya, 1 (1): 87-94. 